\title{
ANALISIS KEMENANGAN DONNA PADA PEMILIHAN LEGISLATIF KABUPATEN TANAH DATAR PERIODE 2014-2019 DAN PERIODE 2019-2024
}

\author{
Fachri Rahmad Aulia \\ Jurusan Ilmu Politik, Fisip, Universitas Andalas \\ Email : rahmadfachri24@gmail.com
}

\begin{abstract}
Abstrak
Perempuan terlibat aktif dalam dunia politik praktis menjadi fenomena yang menarik untuk dibahas. Pasalnya peran perempuan dalam dunia politik praktis sangat minim sekali. Terdapat warna baru yang terjadi dalam kontestasi pemilu legislatif di Kabupaten Tanah Datar dalam kurun waktu Pemilu (2014-2019) dan (2019-2024). Dimana terdapat anggota legislatif perempuan yang berhasil memenangkan pemilu selama 2 (dua) periode (2014 dan 2019) yang bernama Donna. Dimana pada Pemilu 2014 Donna meraih suara sebanyak 912 suara dan 1.599 suara pada Pemilu 2019. Berdasarkan latar belakang permasalahan tersebut peneliti ingin menganalisis kemenangan Donna dengan menggunakan teori partipasi terhadap organisasi, program partai dan kredibilitas. Metode yang digunakan dalam penelitian adalah kualitatif dengan studi kasus. Hasil penelitian menunjukkan bahwa Donna berkonstribusi nyata terhadap partainya yaitu Partai Demokrat. Dimana Donna selalu aktif mengikuti setiap kegiatan pengambilan keputusan, aktif memberikan gagasan, tenaga, materi dan berkontribusi kepada masyarakat. Donna juga berhasil menjalankan program yang diberikan oleh partai kepadanya. Sehingga dengan keberhasilannya itu dapat membuat partai menjadi percaya dan mendukungnya untuk maju lagi menjadi anggota legislatif. Terakhir Donna sangat baik dalam membangun kredibilitas dirinya, hal ini ditandai dengan adanya keahlian komunikasi persuasif yang dimilikinya, adanya kepercayaan yang datang dari masyarakat, dan Donna memiliki daya tarik yang baik sebagai seorang komunikator.
\end{abstract}

Kata Kunci : Pemilu; Partisipasi; Kredibilitas

\begin{abstract}
The phenomenon of women engaging in politics has always been an interesting issue to discuss. This is because the role of women in dynamics in the realm of politics is very minimal. There is a new color that occurs in the contestation of legislative elections in Tanah Datar Regency during the Election (2014-2019) and (2019-2024). Where there is a female legislative member who won the election for 2 periods (2014 and 2019) named Donna. Where in the 2014 Election Donna won 912 votes and 1,599 votes in the 2019 Election. Based on the background of these problems, the researcher wants to analyze Donna's victory using the theory of participation in organizations, party programs and credibility. This research uses qualitative research methods with intrinsic case study research type to find interesting findings to be studied. The results of the study indicate that Donna is very participatory in contributing to her party, namely the Democratic Party. Where Donna always actively participates in every decision-making activity, actively provides ideas, energy, materials and contributes to society. Donna also managed to run the program given to him by the party. So that with its success it can make the party believe and support it to come forward again to become a member of the legislature. Finally, Donna is very good at building her credibility, this is indicated by her persuasive communication skills, the trust that comes from the community, and Donna has a good appeal as a communicator.
\end{abstract}

Keywords: Election; Participation; Credibility 


\section{PENDAHULUAN}

Pemilu tahun 2019 dikatakan sebagai momentum yang tepat bagi perempuan untuk dapat turut serta merepresentasikan diri dalam lembaga legislatif. Hal ini diperkuat dengan adanya UU No. 2 Tahun 2008 yang memuat kebijakan partai politik harus menyertakan keterwakilan perempuan minimal 30\% dalam mengajukan kadernya menjadi calon anggota legislatif. Dengan adanya konstitusi yang mendukung perempuan untuk dapat merepresentasikan dirinya di lembaga legislatif ini, diharapkan mampu meningkatkan kesetaraan gender di dalam sistem pemerintahan negara kita ini. Keterwakilan perempuan di lembaga legislatif tidak hanya penting dari aspek perimbangan antara laki-laki dan perempuan. Populasi Indonesia separuhnya berjenis kelamin perempuan. Namun lebih dari itu, kehadiran anggota parlemen perempuan diharapkan bisa menjamin kepentingan kaum perempuan menjadi salah satu prioritas kebijakan, diantaranya terkait dengan isu pengentasan kemiskinan, pemerataan pendidikan, dan layanan kesehatan.

Terdapat sebuah hal baru yang terjadi dalam kontestasi Pemilihan Legislatif di Kabupaten Tanah Datar Provinsi Sumatera Barat dalam kurun waktu periode Tahun 2014-2019 dan Tahun 2019-2024. Dimana pada rentang Tahun pemilihan legislatif ini terdapat calon legislatif perempuan yang berhasil menduduki kursi di parlemen selama dua periode. Fenomena ini diharapkan mampu memacu asah dan keinginan perempuan untuk turut serta menduduki kursi di parlemen. Sehingga dapat menghilangkan budaya patriarki yang dinilai dapat membuat peran perempuan dalam hal mengisi kursi di parlemen menjadi sangat minim sekali.

Calon legislatif perempuan yang berhasil memenangkan Pemilu Legislatif Di Kabupaten Tanah Datar selama dua periode itu bernama Donna. Donna merupakan calon legislatif perempuan yang diusung oleh Partai Demokrat. Pada Pemilu Tahun 2014 Donna meraih suara sebanyak 912 suara. Dimana Daerah Pemilihan (Dapil) Donna ini yaitu Dapil IV yang meliputi Kecamatan Lima Kaum, Rambatan dan Batipuh Selatan. Sedangkan pada Pemilu Tahun 2019 Donna meraih suara sebanyak 1.599 suara. Dapilnya yaitu Dapil II meliputi Kecamatan Lima Kaum, Rambatan dan Batipuh Selatan. Atas dasar fenomena itulah peneliti tertarik untuk meneliti ihwal kemenangan Donna ini pada kontestasi Pemilihan legislatif 2014 dan 2019.

Beberapa Literatur dan Kajian yang meneliti tentang kemenangan seorang politikus (Caleg atau Kepala Daerah) diantaranya adalah penelitian yang dilakukan oleh Wanda Pratama dengan judul Political Marketing ( marketing politik ) Sitti Izzati Aziz pada Pemilu Legislatif Tahun 2014 di Sumatra Barat. Dengan Product (produk) politik yang ditawarkan oleh Sitti Izzati Aziz adalah melihatkan figur dirinya yang kenyang akan pengalaman organisasi terhadap masyarakat dan juga memanfaatkan figur almarhum orang tuanya untuk menjadi nilai jual terhadap produk politiknya. ${ }^{1}$ Selanjutnya Penelitian

\footnotetext{
${ }^{1}$ Wanda Pratama, "Political Marketing ( Marketing Politik ) Sitti Izzati Aziz Pada Pemilu Legislatif Tahun 2014 Di Sumatra Barat”. Skripsi Pada Jurusan Ilmu Politik FISIP UNAND, Padang, 2016.
} 
yang dilakukan oleh Heru Permana Putra mengenai Perbandingan Strategi Caleg Perempuan Dalam Usaha Memenangkan Pemilu Legislatif 2009 Di Kota Padang ditinjau dengan strategi Segmentasi, Targetting dan Positioning, serta faktor yang perlu dipertimbangkan dalam masyarakat dalam menerapkan strategi politik di dalam Pemilu dan pengelolaan modal sosial yang dimiliki sekitar lingkungannya. ${ }^{2}$

Penelitian yang berjudul "Pemanfaatan Modal Sosial Deri Asta dan Zohirin Sayuti pada Pilkada Sawahlunto Tahun 2018" oleh Wahyuni Chairunnisa. Dalam penelitian tersebut mengkaji pemanfaatan modal sosial, ekonomi, dan politik dalam kemenangan Deri Asta dan Zohirin Sayuti dalam pemilihan Walikota Sawahlunto. Deri Asta dikenal sebagai orang yang dekat dengan masyarakat dan mempunyai jiwa sosial yang tinggi, hal ini terbukti dengan hasil Pilkada Deri Asta dapat mengalahkan petahana. Selain itu, Deri Asta merupakan pengusaha batu bara tentu memiliki hubungan dengan beberapa pengusaha batu bara lainnya yang memberikan bantuan moril maupun materil. ${ }^{3}$

Terakhir penelitian yang dilakukan oleh Yogi Pratama yang berjudul "Jaringan Modal Sosial Kemenangan Pasangan Fadly Amran Dan Asrul Dalam Pemilihan Kepala Daerah Padang Panjang Tahun 2018". Dalam penelitian ini menjelaskan fenomena analisis kemenangan paslon dengan menggunakan konsep Modal sosial dari Robert Putnam. Jaringan politik merupakan turunan dari konsep modal sosial ini yaitu Jaringan, Kepercayaan, Norma. Ketiga hal itu saling berkaitan sehingga terbentuknya jaringan yang kuat.

Tujuan dari penelitian ini adalah mengetahui modal sosial apa yang dimiliki pasangan Fadly Amran dan Asrul sebelum mengikuti Pilkada Padang Panjang tahun 2018. Serta melihat bagaimana pengaruh jaringan sosial yang dimiliki oleh pasangan Fadly Amran dan Asrul sehingga dapat memenangkan Pilkada Padang Panjang tahun 2018. Metode yang dilakukan dalam penelitian ini adalah kualitatif. Teknik pengumpulan data yang dilakukan dalam penelitian tersebut adalah dokumentasi dan wawancara. ${ }^{4}$

Berbeda dengan penelitian terdahulu yang pada umumnya menggunakan tinjauan teori marketing politik dan modal sosial dalam menganalisis kemenangan seorang politisi. Penelitian ini memiliki novelty dan keunikan tersendiri. Dalam menganalisis kemenangan seorang calon legislatif perempuan, peneliti ingin menggunakan teori organisasi politik (parpol) dan kredibilitas sebagai pisau analisis peneliti dalam mengekspolarasi faktor yang menyebabkan caleg perempuan "Donna" menang dalam kontestasi Pemilihan Legislatif selama dua periode (Pileg 2014 dan 2019). Donna merupakan calon legislatif perempuan yang berhasil memenangkan kontestasi pemilu legislatif pada dua periode. Dimana pada pemilihan legislatif tahun 2014 beliau juga memenangkan kontestasi pemilu legislatif tersebut.

\footnotetext{
${ }^{2}$ Heru Permana Putra, "Perbandingan Strategi Anggota Legislatif Perempuan Di DPRD Kota Padang Pada Pemilu Legislatif Tahun 2009”. Skripsi Pada Jurusan Ilmu Politik FISIP UNAND, Padang,2011.

${ }^{3}$ Wahyuni Chairunnisa, "Pemanfaatan Modal Sosial Deri Asta dan Zohirin Sayuti pada Pilkada Sawahlunto Tahun 2018”. Skripsi Pada Jurusan Ilmu Politik FISIP UNAND, Padang,2019.

${ }^{4}$ Yogi Pratama "Jaringan Modal Sosial Kemenangan Pasangan Fadly Amran Dan Asrul Dalam Pemilihan Kepala Daerah Padang Panjang Tahun 2018. Skripsi Pada Jurusan Ilmu Politik FISIP UNAND. Padang. 2019
} 
Atas kemenangan pada pileg 2019 inilah membuat Donna menjadi satu-satunya calon legislatif perempuan di Kabupaten Tanah Datar yang berhasil memenangkan kontestasi politik pada dua periode. Donna juga mendapatkan peningkatan perolehan jumlah suara dibandingkan pemilihan legislatif Tahun 2014. Dimana pada pemilihan legislatif tahun 2014 mendapatkan perolehan suara sebanyak 912 suara dan pada pemilihan legislatif tahun 2019 mendapatkan perolehan suara sebanyak 1.599 suara. ${ }^{5}$ Terjadinya peningkatan suara yang didapatkan oleh Donna sebanyak 687 suara merupakan suatu kebanggaan dan prestasi sendiri bagi beliau, keluarga, kerabat dan partai pengusungnya yaitu Partai Demokrat. Ini pertama kalinya juga dalam sejarah kancah perpolitikan di Kabupaten Tanah Datar mengingat pada kontestasi pemilu sebelumnya belum ada calon legislatif perempuan yang berhasil menang dalam 2 kali periode pemilihan legislatif. ${ }^{6}$

Penelitian ini akan fokus membahas tentang analisis kemenangan Donna yang merupakan salah satu kandidat perempuan Minangkabau khususnya di Kabupaten Tanah Datar yang memenangkan dua periode pemilihan legislatif yaitu pada periode 2014-2019 dan periode 2019-2024. Donna merupakan anggota legislatif yang berasal dari partai Demokrat yang mampu bersaing dengan memenangkan dua periode. Berdasarkan fenomena-fenomena yang telah peneliti jelaskan di latar belakang, penelitian ingin menganalisis Kemenangan Donna dalam pemilu legislatif tahun 2014 dan 2019 di Kabupaten Tanah Datar. Peneliti berasumsi bahwa faktor yang dominan berperan atas kemenangan Donna pemilu legislatif tahun 2014 dan 2019 di Kabupaten Tanah Datar adalah Kredibilitas yang dimiliki oleh Donna dan Peran Partai Politik yang mengusung Donna tersebut.

Peneliti berasumsi bahwa salah satu faktor yang menyebabkan Donna dapat memenangkan pemilihan legislatif ini adalah dengan adanya kredibilitas yang telah dibangun oleh Donna. Seperti kinerja yang produktif yang telah dilakukannya dalam masa jabatan pertamanya sebagai anggota DPRD Kabupaten Tanah Datar, memberikan konstribusi yang relatif positif kepada partai politiknya, turut serta terjun ke masyarakat terutama masyarakat yang berada dalam kawasan daerah pemilihannya dan konstribusi lainnya yang diberikannya. Selama menjadi anggota DPRD Donna tidak pernah melupakan masyarakat yang telah memilihnya dan selalu menyerap aspirasi yang datang dari masyarakat di dapilnya. Dana aspirasi yang ada padanya diberikan untuk pembangunan Infra struktur di dapil IV yang meliputi (Kecamatan Lima Kaum, Rambatan dan Batipuh Selatan) dan juga untuk pemberdayaan masyarakat. Setiap masyarakat meminta bantuan dia selalu membantu dan telah banyak melimpahkan dana aspirasi yang diberikan kepada nagari-nagari yang ada di dapil IV dan terutama di Nagari Baringin. ${ }^{7}$

\footnotetext{
${ }_{6}^{5} \mathrm{http} / / / \mathrm{www}$. portalberitaeditor.com

${ }^{6} \mathrm{http}: / / \mathrm{www} \cdot \mathrm{minangkini.com}$

${ }^{7}$ http://www.portalberitaeditor.com/dra-donna-terpilih-lagi-jadi-anggota-dprd-kab-tanah-datar/.Diakses pada tanggal 20 Januari 2021. Pukul 17.00 WIB
} 
Sehingga masyarakat, partai politik, dan kolega Donna di kepemerintahan legislatif menjadi percaya terhadap Donna tersebut. Atas kepercayaan ini lah orang-orang mau untuk memberikan suaranya kepada Donna sehingga Donna dapat memenangkan lagi kontestasi pemilihan legislatif pada Pemilu 2019 Kabupaten Tanah Datar. Selain itu peneliti meyakini bahwa peran Partai Demokrat yang notabene merupakan partai politik yang mengusung Donna menjadi wakil rakyat memberikan konstribusi yang dominan pula atas kemenangan Donna ini. Baik itu dalam hal mengurus persoalan administrasi, memberikan modal financial kepada Donna, merumuskan sekaligus memasarkan tentang visi misi Donna ini kepada masyarakat dan lainnya. Partai Demokrat merupakan partai yang mengusung Donna untuk maju menjadi calon legislatif DPRD Kabupaten Tanah Datar selama dua periode (2014-2019 dan 2019-2024).

Oleh karena itu peneliti meyakini partai Demokrat ini memiliki pengaruh yang sangat kuat sekali atas kemenangan Donna menjadi caleg selama dua periode ini. Oleh karena itu peneliti merumuskan permasalahan dalam suatu rumusan masalah yaitu : "Apa Faktor Penyebab Kemenangan Donna Pada Pemilihan Legislatif Kabupaten Tanah Datar Periode 2014-2019 Dan Periode 2019-2024 jika dihubungkan dengan Faktor Partisipasi Donna terhadap Organisasi Politik (Partai Politik), Kinerja Donna dalam menjalankan Program yang diberikan oleh Partai Politk dan Refleksi dari Kredibilitas yang dimiliki oleh Donna".

\section{Partisipasi Kader dan Program Partai Politik}

Secara umum partisipasi berarti mengambil bagian dari suatu tahap atau lebih dari suatu proses. Adapun proses yang dimaksud tentu saja proses pembangunan. Sedangkan konsep partisipasi menurut Pamuji (1985) dalam Dawy (1992:10) mencakup kerjasama antara semua unsur terkait dan merupakan suatu kesepakatan, harapan, persepsi dan sistem komunikasi. Dimana tingkat kemampuan dan pendidikan turut mempengaruhi sikap dan cara seseorang berprilaku. ${ }^{8}$

Narine dalam (Midgley, 1986: 113) menyatakan bahwa partisipasi memiliki arti sebagai hubungan dengan pihak lain dalam sebuah ikatan dengan hak-hak dan kewajiban tertentu, dan di dalamnya ada pembagian keuntungan di antara pihak-pihak yang mengambil bagian. ${ }^{9}$ Dalam proses seperti itu, partisipasi paling tidak memerlukan kesediaan dua arah dari dua pihak tersebut. Dalam pengertian lebih lanjut, partisipasi membutuhkan sebuah wadah untuk menjaga hak dan kewajiban pihakpihak yang terlibat dalam kerangka itu, termasuk di dalamnya dalam perolehan bagian keuntungan akibat hubungan yang terjadi. Peran serta merupakan bentuk hubungan yang saling menguntungkan.

Dalam konteks dinamika organisasi dalam partai politik, partisipasi kader membicarakan tentang intensitas anggota (kader) dari sebuah partai politik (kader partai

\footnotetext{
${ }^{8}$ Dawy, H.M. 1992. Partisipasi Masyarakat dalam Pengembangan Kepariwisataan Yang Berwawasan Lingkungan. Ujung Pandang: Program Pascasarjana UNHAS.

${ }^{9}$ Midgley, J. 1986. Introduction: Social Development in Midgley J. Et All Community participation social development and the state. London: Meuthen.Co.
} 
politik) dalam mengemban tugas dan amanahnya sebagai kader. Seorang kader partai yang optimal berperan dalam melaksanakan tugasnya dapat dikatakan bahwa kader tersebut telah berpartisipasi dengan baik terhadap partai. Partisipasi dalam ruang lingkup partai politik dapat pula dikenal dari keterlibatan seseorang kader dalam bentuk kontribusinya terhadap organisasi partai politik. (Pabeta, 1992:4) mengemukakan ciri-ciri seseorang yang berpartisipasi dalam sebuah organisasi adalah sebagai berikut: ${ }^{10}$

1. Terlibat dalam kegiatan pengambilan keputusan yang mencakup tentang mengambil dan menjalankan keputusan.

2. Partisipasi dalam menyumbangkan gagasan, tenaga dan materi.

3. Kemampuan bekerja sama

4. Berperan terhadap masyarakat

Lovenduski dan Norris (1993:12) membahas tentang bagaimana program yang datang dari sebuah partai. ${ }^{11}$ Dikatakan disini program adalah menyangkut hal-hal mengenai apa yang akan dan tidak akan dilakukan oleh partai baik sebagai pencerminan ideologi maupun kepentingan. Pada penelitian ini peneliti akan menghubungkan dua konsepsi teoritis partisipasi kader perempuan terhadap partai politik dan mengidentifikasi program apa-apa saja yang dilakukan oleh partai politik Donna sehingga Donna dapat memenangkan kontestasi politik Pemilihan Legislatif dalam Pileg 2014 dan 2019.

\section{Kredibilitas}

Kredibilitas merupakan kualitas, kapabilitas, dan kekuatan yang dimiliki oleh seseorang atau kelompok untuk menimbulkan kepercayaan dari orang lain. Kredibilitas ini dapat dimiliki oleh seseorang atau kelompok apabila orang tersebut memiliki nama baik, reputasi baik, kehormatan dan keberadaan bagi orang atau lembaga yang menonjol di antara komunitasnya. Hal tersebut akan dipandang sebagai nilai jual positif dan menjadi nilai lebih bagi pemiliknya. Atas segelintir prestasi baik yang telah diraih oleh orang atau kelompok kredibel inilah menjadikan sebuah alasan bagi orang-orang yang kredibel tersebut mendapatkan kepercayaan dari publik.

Terdapat tiga komponen kredibilitas sumber, yakni keahlian, kepercayaan dan daya tarik. Faktor keahlian adalah tingkat penguasaan sumber yang dipersepsi khalayak mengetahui jawaban yang benar dan tepat pada pokok permasalahan. Keahlian bergantung pada keterlatihannya, pengalamannya, kemampuannya dan status sosialnya, jadi seorang sumber dikatakan ahli adalah seorang yang pengetahuannya diakui dan dipercaya tentang pokok permasalahan. Kepercayaan adalah kesan audience tentang komunikator berkaitan dengan watak atau kepribadianya. Komunikator yang dapat dipercaya adalah komunikator yang dianggap jujur, tulus, bermoral, adil, sopan atau etis (Rakhmad, 2012:257

\footnotetext{
${ }^{10}$ Pabeta. 1992. Meningkatkan Partisipasi Terhadap Organisasi. Jakarta : PT Gramedia Pustaka Jaya

${ }^{11}$ Lovenduski, Joni \& Norris, Pippa. 1993. Gender and Party Politics. London: Sage Publications
} 
Faktor berikutnya adalah daya tarik adalah sebagai salah satu komponen pelengkap dalam pembentukan kredibilitas sumber. Menurut Rakhmad (2012:112) daya tarik komunikator adalah daya tarik dari penampilan fisik (physic) dan juga daya tarik psikologis yang terdiri dari kesamaan (similarity), dikenal (familiarity), atau kesukaan (liking) ${ }^{12}$. Kesamaan atau similarity dimaksudkan agar orang bisa tertarik pada komunikator karena adanya kesamaan demografi, seperti bahasa, agama, daerah asal, maupun ideologi. Familiarity maksudnya seorang komunikator yang dikenal baik lebih diterima oleh audience daripada mereka yang tidak dikenal. Komunikator yang sudah dikenal kepiawaiannya akan mudah diterima, sebab audience tidak akan ragu terhadap kemampuan dan kejujurannya. Kesukaan atau liking artinya komunikator yang disukai karena penampilan fisiknya, adanya kesamaan, atau dikenal baik akan lebih memiliki daya tarik.

\section{METODE PENELITIAN}

Dalam penelitian ini, peneliti menggunakan metode pendekatan kualitatif untuk menggambarkan dan menganalisis faktor penyebab Kemenangan Donna Pada Pemilihan Legislatif Kabupaten Tanah Datar Periode 2014-2019 Dan Periode 2019-2024. Pendekatan Kualitatif merupakan prosedur penelitian, yang menghasilkan data deskriptif berupa kata-kata tertulis atau lisan dari orang-orang dan perilaku yang diamati. ${ }^{13}$ Tipe penelitian yang peneliti gunakan dalam meneliti masalah ini adalah tipe penelitian kualitatif dengan metode studi kasus. Metode Studi Kasus merupakan metode penelitian kualitatif yang meneliti suatu kasus atau fenomena tertentu yang ada dalam masyarakat yang dilakukan secara mendalam untuk mempelajari latar belakang, keadaan, dan interaksi yang terjadi. Studi Kasus dilakukan pada suatu kesatuan sistem yang bisa berupa suatu program, kegiatan, peristiwa atau sekelompok individu yang ada pada keadaan atau kondisi tertentu.

Pada penelitian ini peneliti menggunakan jenis penelitian studi kasus intrinsik. Studi kasus intrinsik merupakan penelitian yang meneliti apabila kasus yang diteliti dipelajari secara mendalam dikarenakan di dalam kasus tersebut terdapat hal-hal yang menarik untuk dipelajari. Dikatakan kasus tersebut mengandung minat intrinsik (intrinsic interest). ${ }^{14}$ Oleh karena itulah dasar peneliti menggunakan metode studi kasus ini karena peneliti ingin mendapatkan dan mempelajari data yang mendalam dan substansial terkait data yang mempunyai korelasi yang kuat terhadap kemenangan Donna dalam mengikuti pemilihan legisatif pada periode 2014-2019 dan periode 2019-2024.

\footnotetext{
${ }^{12}$ Rakhmad, Jalaludin. 2012. Psikologi Komunikasi. Remaja Rosda Karya, Bandung.

13 Lexy J.Moleong, Metodologi Penelitian Kualitatif, PT Remaja Rosdakarya, Bandung, 2014, hal: 3

14 Basuki, H. 2006. Penelitian Kualitatif Untuk Ilmu Kemanuasiaan dan Budaya. Depok: Universitas Gunadarma.
} 


\section{HASIL DAN PEMBAHASAN}

\section{a. Partisipasi Donna Terhadap Organisasi Partai Politik}

\section{Terlibat dalam kegiatan pengambilan keputusan yang mencakup tentang} mengambil dan menjalankan keputusan.

Dalam melihat apakah seorang anggota partai berpartisipasi terhadap partainya dapat dilihat dengan beberapa indikator. Salah satunya dengan melihat apakah anggota partai tersebut aktif dalam kegiatan-kegiatan pengambilan keputusan seperti rapat, kongres, sidang dan lainnya. Berdasarkan data yang peneliti temukan di lapangan, Donna termasuk sebagai kader partai yang aktif yang terlibat dalam kegiatan pengambilan keputusan. Temuan ini didapatkan berdasarkan hasil wawancara peneliti dengan Ibuk Donna itu sendiri yang mengatakan:

"Saya selalu mengikuti segala kegiatan yang diagendakan oleh partai. Contohnya Saya juga selalu mengikuti kegiatan rapat internal di kepartaian saya yaitu Partai Demokrat. Saat rapat saya selalu rutin memberikan saran-saran sekaligus juga mengingatkan kepada seluruh kader partai agar program yang akan dibuat dan dijalankan tersebut, orientasinya selalu akan memenuhi kepentingan masyarakat banyak". ${ }^{15}$

Dikatakan Donna selalu rajin dalam mengikuti agenda seperti rapat serta selalu aktif dalam menyumbangkan gagasan. Topik Gagasan yang selalu disampaikan oleh Donna ketika ada agenda rapat di kepartaian memiliki bobot dan mudarat sekali dalam menunjang eksistensi partai. Dimana Donna selalu memberikan gagasan yang mementingkan pemenuhan kebutuhan masyarakat. Jika program sebuah partai selalu berorientasikan akan pemenuhan kepentingan rakyat dikatakan partai tersebut telah militan dalam memainkan perannya sebagai salah satu instrumen penting dalam proses demokratisasi untuk mewujudkan pemerintahan yang demokrasi. Pernyataan Donna ini juga didukung oleh Pernyataan Nurhamdi Zahari selaku sebagai Sekretaris DPC Partai Demokrat Kabupaten Tanah Datar 2014 dan Ketua DPC Partai Demokrat Kabupaten Tanah Datar 2019.

"Kalau dalam hal rapat Donna juga aktif dalam menyumbangkan gagasan terkhusus dalam memberikan gagasan yang bertujuan untuk mensejahterakan kaum perempuan. Contohnya waktu itu ketika beliau mengusulkan adanya kegiatan temu ramah dan kerjasama dengan organisasi-organisai wanita dan juga ibuk-ibuk di Kabupaten Tanah Datar ini. Di rapat atau sidang di DPRD Donna ini sangat berperan sekali dalam membawa aspirasi partai agar dapat tembus menjadi sebuah keputusan". ${ }^{16}$

Disimpulkan bahwa Donna merupakan kader yang loyal terhadap partai. Argumen ini dibuktikan oleh pendapat Ketua DPC Partai Demokrat Kabupaten Tanah Datar yang mengatakan Donna selalu mengikuti setiap kegiatan dan menjalankan kewajibannya dengan baik sejak awal menjadi anggota partai. Hanya faktor kesehatan

\footnotetext{
${ }^{15}$ Wawancara dengan Donna Anggota DPRD Perempuan Kabupaten Tanah Datar (2014-2019) dan (20192024) bertempat di Kantor DPRD Kabupaten Tanah Datar Pada Tanggal 1 Maret 2021 Pukul 11.46 WIB

${ }^{16}$ Wawancara dengan Nurhamdi Zahari Sekretaris DPC Partai Demokrat Kabupaten Tanah Datar 2014 dan Ketua DPC Partai Demokrat Kabupaten Tanah Datar 2019 di kediamannya Pada Tanggal 2 Maret Pukul 11.01 WIB
} 
dan urusan privasi seperti urusan keluarga yang dianggap penting dan mendesak yang dapat mengalihkan prioritasnya terhadap partai.

Berdasarkan temuan data peneliti dapat dikatakan bahwa Donna merupakan anggota legislatif yang aktif dalam kegiatan pengambilan keputusan di partainya dan baik dalam menjalankan keputusan tersebut. Sehingga membuat intensitas kepercayaan partai terhadapnya menjadi meningkat. Temuan ini selaras dengan pendapat dari informan triangulasi penelitian ini yaitu Dr. Indah Adi Putri yang merupakan Dosen Ilmu Politik yang mengatakan:

"Dalam pandangan teori modal sosial, kepercayaan akan tumbuh seiring dengan intensitas interaksi antar individu atau kelompok. Semakin sering interaksi dilakukan, terlebih dalam interaksi yang memberi manfaat timbal balik, maka akan semakin besar kepercayaan yang terbangun. Sehingga bila dikaitkan dengan kasus aleg ini maka, kepercayaan bisa semakin besar". ${ }^{17}$

\section{b. Partisipasi Dalam Menyumbangkan Gagasan, Tenaga dan Materi}

Indikator selanjutnya dalam melihat apakah seorang anggota partai berpartisipasi terhadap partainya dapat dilihat dengan konstribusinya dalam menyumbangkan gagasan, tenaga dan materi kepada partai. Berdasarkan data yang peneliti temukan di lapangan, Donna termasuk sebagai kader partai yang aktif dalam memberikan gagasan. Temuan ini didapatkan berdasarkan hasil wawancara peneliti dengan Ibuk Donna itu sendiri yang mengatakan:

"Insyaallah sejauh saya menjadi kader partai demokrat ini saya selalu aktif dalam mengikuti, memberikan gagasan dan memberikan solutif dalam rapat-rapat yang diadakan oleh partai. Saya selalu mengingatkan kepada rekan-rekan partai bahwa dalam merumuskan dan menyelenggarakan kegiatan itu orientasinya harus mengutamakan kepentingan masyarakat. Lalu kepada rekan-rekan partai yang juga menjabat menjadi anggota DPRD selalu saya ingatkan untuk maksimal dalam menyerap aspirasi masyarakat. Terlebih lagi pada saat momentum kegiatan reses. Dimana reses merupakan kegaiatan bagi wakil rakyat untuk terjun ke masyarakat pada dapil masingmasing untuk melihat permasalahan yang ada, menampung aspirasi masyarakat dan memberikan solutif dalam mengatasi permasalahan yang terjadi dalam kehidupan masyarakat". ${ }^{18}$

Selama Donna menjadi anggota Partai Demokrat, Donna selalu aktif berpartisipasi dalam menyumbangkan gagasan serta memberikan solusi dalam memecahkan sebuah masalah. Donna juga mengingatkan agar setiap program yang direncanakan dan dilaksanakan oleh partai agar mengutamakan kepentingan rakyat. Lalu Donna juga mengingat kepada rekan partai yang menjadi anggota DPRD agar maksimal menyerap aspirasi rakyat sewaktu melaksanakan kegiatan reses. Pernyataan yang

\footnotetext{
${ }^{17}$ Wawancara dengan Dr. Indah Adi Putri Dosen Jurusan Ilmu Politik Universitas Andalas Melalui Aplikasi WhatsApp Pada Tanggal 16 Maret 2021 Pukul 21.34 WIB

${ }^{18}$ Wawancara dengan Donna Anggota DPRD Perempuan Kabupaten Tanah Datar (2014-2019) dan (2019-2024) bertempat di Kantor DPRD Kabupaten Tanah Datar Pada Tanggal 1 Maret 2021 Pukul 11.46 WIB
} 
disampaikan oleh Donna ini memang penting sekali bagi anggota DPRD agar anggota DPRD dapat menjembatani aspirasi yang datang dari rakyat.

Lalu pada momen reses ini seorang anggota DPRD dapat melakukan tinjauan langsung dan mencari apa-apa saja permasalahan dan hal-hal yang harus dibenahi pada wilayah dapilnya. Seseorang anggota DPRD yang optimal kinerjanya dalam masa reses akan dapat membuat image masyarakat terhadapnya menjadi positif. Serta dapat juga merawat dan meningkatkan basis konstituen dari seorang anggota DPRD tersebut. Tidak tertutup kemungkinan juga efek positif ini juga akan mengalir ke partai politik yang mengusungnya.

Dalam hal partisipasi memberingkan sumbangsih materi kepada partai, Donna sendiri selalu rutin dalam menyumbangkan barang materi seperti uang atau donasi kepada partai. Sehingga kegiatan operasional partai dapat terus terlaksana dan tidak menjadi stag. Lalu Nurhamdi Zahari juga mengemukakan mengenai sumbangsih materi yang diberikan oleh Donna kepada partai.

"Banyak juga itu, contohnya kalau partai ini mekanisme fungsionalnya kan bersifat sosial dan politik. Dalam setiap kegiatan-kegiatan itu Donna selalu berpartisipasi dalam menyumbang seperti memberikan sumbangan untuk membeli kebutuhan makanan dan minuman. Memberikan bantuan kepada teman-teman yang sakit juga. Dan itu beliaulah yang menjadi inisiatornya. Sehingga dengan itu kader-kader lain juga ikut tergerak hatinya". ${ }^{19}$

Peneliti menemukan temuan menarik yang menyebutkan Donna sebagai inisiator dalam hal memberikan sumbangsih materi ke partai. Nah dengan inisiatif Donna tersebut para-para rekan partai juga menjadi bergerak untuk berpartisipasi memberikan sumbangsih materi kepada partai. Dalam hal ini Donna telah melakukan mobilisasi konsensus kepada rekan partainya. Sukmana (2016:155) menjelaskan mobilisasi konsensus adalah usaha untuk membangkitkan semangat dukungan dan proses yang harus dilalui oleh sebuah gerakan organisasi untuk mencapai tujuan bersama. ${ }^{20}$

\section{c. Kemampuan Bekerja Sama Donna}

Indikator selanjutnya dalam melihat apakah seorang anggota partai berpartisipasi terhadap partainya dapat dilihat dengan melihat kemampuannya dalam bekerja sama dengan sesama anggota partainya. Berdasarkan data yang peneliti temukan di lapangan, Donna termasuk sebagai kader partai yang mampu membangun solidaritas kerja sama dengan rekan partainya. Temuan ini didapatkan berdasarkan hasil wawancara peneliti dengan Ibuk Donna itu sendiri yang mengatakan:

"Alhamdulilah kami selalu bekerja sama dengan baik. Saya sendiri juga selalu menjadi pribadi yang baik dan menyenangkan bagi organisasi saya. Kami pun saling mengisi dan

\footnotetext{
${ }^{19}$ Wawancara dengan Nurhamdi Zahari Sekretaris DPC Partai Demokrat Kabupaten Tanah Datar 2014 dan Ketua DPC Partai Demokrat Kabupaten Tanah Datar 2019 di kediamannya Pada Tanggal 2 Maret Pukul 11.01 WIB

${ }^{20}$ Sukmana, Oman. 2016. Konsep dan Teori Gerakan Sosial. Malang : Intrans Publishing.
} 
melengkapi sehingga kelemahan-kelemahan yang ada dapat teratasi, paling tidak terminimalisir. Saya selalu menunjukkan wawasan mengenai hal-hal yang tidak diketahui oleh rekan-rekan partai saya sehingga rekan saya menjadi bertambah wawasannya. Perlu diingat kami ini para pengurus partai demokrat DPC Kabupaten tanah Datar ini, tidak hanya dalam sebatas persoalan politik saja menjalin hubungan atau melakukan komunikasi. Persoalan yang urusannya tidak politik kami selalu melakukan komunikasi. Atas dasar itu juga hubungan emosional dan silaturrahmi ini menjadi kuat sehingga menjadi nyaman dalam bekerja". ${ }^{21}$

Salah satu langkah yang dilakukan oleh Donna dalam membangun kerja sama dalam lingkaran partai adalah dengan berbagi pengetahuan akan ilmu-ilmu yang dia miliki kepada rekan-rekan partai. Donna selalu melakukan komunikasi antar sesama anggota partai sehingga dengan itulah hubungan silaturrahmi anatara dirinya dengan rekan-rekan partai dapat terus terbangun dan terjaga. Dikatakan bahwa Donna sering berperan sebagai kader partai yang menyampaikan gagasan, pandangan dan sikap dari partai dalam sidang di DPRD Kabupaten Tanah Datar. Selain itu Donna juga aktif menjadi delegasi partainya dalam merespon, memberikan masukan dan memberikan kritik. Disebutkan Donna berperan sekali sebagai seorang komunikator politik. Menurut Nimmo (1993: 72) politisi sebagai komunikator politik berkomunikasi sebagai wakil suatu kelompok dalam menyampaikan kepentingan-kepentingan dari kelompok politiknya (partai politik). ${ }^{22}$

\section{d. Peran Donna Kepada Masyarakat}

Berdasarkan wawancara peneliti dengan Donna dikatakan bahwa Donna sebelum menjabat menjadi anggota DPRD telah sering bergaul dan berinteraksi dengan masyarakat. Hal ini dilakukannya memang karena memiliki niat untuk ingin selalu menjalin silaturrahmi dengan masyarakat. Terlebih lagi dengan adanya figur orang tua dari Donna yang popular di kalangan masyarakat membuat keinginannya untuk melanjutkan aksebilitas silaturrahmi dengan masyarakat jadi tinggi pula. Konstribusi ke masyarakat yang dilakukan oleh Donna seperti menjadi donatur dalam pembangunan infrastruktur umum, membantu masyarakat yang kurang mampu dan memberikan beasiswa pendidikan kepada anak-anak yang sedang menempuh pendidikan. Nurhamdi Zahari menambahkan juga pernyataan Donna ini tentang peran yang diberikannya kepada masyarakat sebelum Pemilihan Umum Legislatif 2014 di Kabupaten Tanah Datar.

"Kalau saya melihat kontribusinya tu yang sebenarnya itu jiwa kepedulian terhadap masyarakatnya itu yang sangat tinggi sekali. Misalnya ada masyarakat yang sedang dilanda bencana kebakaran, banjir bandang dia langsung datang ke situ. Pokoknya Donna ini sangat peduli ke masyarakat, sehingga karena itulah masyarakat jadi mau memilihnya. Walupun pada waktu itu Donna belum pernah menjadi anggota DPRD.

\footnotetext{
${ }^{21}$ Wawancara dengan Donna Anggota DPRD Perempuan Kabupaten Tanah Datar (2014-2019) dan (20192024) bertempat di Kantor DPRD Kabupaten Tanah Datar Pada Tanggal 1 Maret 2021 Pukul 11.46 WIB

22 Nimmo, Dan. 1999. Komunikasi Politik (Komunikator, Pesan dan Media). Bandung : Remaja Rosdakarya
} 
Perlu diketahui Donna ini memang sering bergaul dan berinteraksi dengan masyarakat jauh sebelum dia menjajal dunia politik ini". ${ }^{23}$

Berdasarkan pernyataan dari hasil wawancara tersebut Donna menjadi lebih aktif dan sering dalam hal melakukan pengabdian kepada masyarakat. Lanjut Donna mengatakan tentang konstribusinya ke masyarakat saat menjadi anggota DPRD:

"Setelah masuk ke DPRD, di DPRD tu kan ada program yang bernama dana aspirasi. Dimana dana tersebut digunakan anggota DPRD ketika ingin menjaring aspirasi masyarakat yang momentumnya itu pada kegiatan reses. Contoh waktu saya Reses di Parak juar Nagari Baringin Kecamatan Lima Kaum. Di DPRD tu kan ada anggaran pertahun DPRD untuk melaksanakan proker DPRD, nah hasil reses saya di Parak Jua yang contohnya mengusulkan anggaran untuk memperbaiki jalan di Jorong Parak jua tersebut nanti kita masukkan dalam program pembangunan daerah nantinya. Selama ini itu yang saya lakukan di berbagai tempat di dapil saya. Dan Alhamdulilah usulan tersebut banyak yang terumuskan. Tidak hanya itu ada juga berbagai pembangunan fisik lainnya seperti aspirasi yang datang untuk memperbaiki tempat ibadah seperti Musola, jembatan dan infrastruktur lainnya". ${ }^{24}$

Dikatakan Donna efektif dalam menggunakan dana aspirasi dari DPRD, yang dipergunakan pada saat melakukan agenda reses. Sehingga jangkauan dan pemetaan masalah yang dilakukannya kepada masyarakat juga menjadi efektif. Hal ini terlihat saat melakukan kegiatan reses di Nagari Baringin Kecamatan Lima Kaum. Dimana hasil resesnya yang mengusulkan program perbaikan jalan di Jorong Parak Juar di Nagari Baringin tersebut dapat diterima oleh pemerintah daerah. Aspirasi pembangunan lain seperti renovasi tempat ibadah, jembatan juga diserap dan diperjuangkan oleh Donna.

\section{e. Program Yang Diberikan Partai Kepada Donna}

Lovenduski dan Norris (1993:12) yang membahas tentang bagaimana program yang datang dari sebuah partai. ${ }^{25}$ Program adalah menyangkut hal-hal mengenai apa yang akan dan tidak akan dilakukan oleh partai baik sebagai pencerminan ideologi maupun kepentingan. Dalam artian apa dan bagaimana substansi dari program-program yang diberikan oleh partai politik tersebut kepada kadernya. Pada pembahasan ini peneliti akan membahas apa saja program yang diberikan oleh Partai Demokrat sebagai partai yang mengusung Donna maju menjadi calon legislatif DPRD Kabupaten Tanah Datar pada tahun 2014 dan 2019.

\footnotetext{
${ }^{23}$ Wawancara dengan Nurhamdi Zahari Sekretaris DPC Partai Demokrat Kabupaten Tanah Datar 2014 dan Ketua DPC Partai Demokrat Kabupaten Tanah Datar 2019 di kediamannya Pada Tanggal 2 Maret Pukul 11.01 WIB

${ }^{24}$ Wawancara dengan Donna Anggota DPRD Perempuan Kabupaten Tanah Datar (2014-2019) dan (20192024) bertempat di Kantor DPRD Kabupaten Tanah Datar Pada Tanggal 1 Maret 2021 Pukul 11.46 WIB

${ }^{25}$ Lovenduski, Joni \& Norris, Pippa. 1993. Gender and Party Politics. London: Sage Publications
} 


\section{Program Yang Diberikan Partai Kepada Donna Menjelang Pemilihan Legislatif Kabupaten Tanah Datar Tahun 2014}

Sebelum pemilihan legislatif tahun 2014, Donna sendiri belum menjadi anggota DPRD di Kabupaten Tanah Datar. Bentuk program yang diberikan partai kepada Donna lebih kepada program-program yang berorientasi kepada masyarakat. Dengan tujuan agar masyarakat dapat melabuhkan pilihan politiknya ke partai Demokrat. Ditekankan juga saat melaksanakan program tersebut agar selalu membawa nama partai sehingga masyarakat dapat mengetahui mengenai esensi sebenarnya dari organisasi partai. Temuan ini peneliti dapat melalui wawancara dengan Nurhamdi Zahari yang merupakan Sekretaris DPC Partai Demokrat Kabupaten Tanah Datar Tahun 2014.

"Lebih ke memberikan dan memfokuskan program-program kemasyarakaan. Contohnya sosialisasi, blusukan. Disamping itu disertakan juga agar selalu membawa embel-embel partai. Agar partai demokrat mendapatkan kepercayaan di hati masyarakat", ${ }^{26}$

Dalam mengemban tugas tersebut Donna menjadi salah satu kader yang berhasil dalam melaksanakan tanggung jawabnya sebagai kader Partai Demokrat.

"Bisa dikatakan berhasil karena banyak sekali konstituen yang dibawanya. Perlu diingat saat itu Partai Demokrat di tingkat nasional sangat banyak sekali masalah yang datang menghampiri. Seperti banyak kader partai nasional yang terjerat kasus korupsi contohnya mantan ketua umum Partai Demokrat Anas Urbaningrum, Angelina Sondakh, kasus Nazaruddin terkait korupsi pembangunan wisma atlit. Lalu ditambah lagi dengan tidak dapatnya Bapak SBY untuk maju lagi menjadi calon presiden karena sudah 2 periode menjabat. Awalnya kita khawatir sekali apabila hal tersebut berefek yang signifikan terhadap eksistensi partai demokrat di Kabupaten Tanah Datar ini. Alhamdulilah dengan giatnya para kader bekerja seperti yang dilakukan oleh Donna basis konstituen yang telah lama ada itu dapat terawat".

Dapat dikatakan kalau Donna sendiri berhasil dalam melaksanakan program kemasyarakatan yang digagas oleh partainya. Terdapat temuan menarik dari hasil wawancara tersebut yang mengatakan eksistensi Partai Demokrat dapat tetap terjaga di Kabupaten Tanah Datar ditengah banyak kasus korupsi yang melanda tokoh partai tersebut dalam kancah politk nasional. Maurice Duferger (2012) mengatakan tujuan politik dari sebuah partai politik dapat tercapai jika anggota kader partai loyal terhadap partai, kelompok elite partai dapat menentukan arah kebijakan partai dan para pengurus partai professional dan millitan dalam bekerja. ${ }^{27}$ Begitu juga yang dilakukan oleh Donna yang tetap giat dalam bekerja sehingga eksistensi Partai Demokrat di Kabupaten Tanah Datar tidak terkikis secara signifikan. Mengapresiasi kinerja dari Donna tersebut Nurhamdi mengatakan Partai Demokrat memberikan reward kepada Donna dengan memberikan nomor urut DCT 2 kepadanya.

\footnotetext{
${ }^{26}$ Wawancara dengan Nurhamdi Zahari Sekretaris DPC Partai Demokrat Kabupaten Tanah Datar 2014 dan Ketua DPC Partai Demokrat Kabupaten Tanah Datar 2019 di kediamannya Pada Tanggal 2 Maret Pukul 11.01 WIB

${ }^{27}$ Mauruce Duferger. 2012. Sosiologi Politik. Jakarta : Gramedia Pustaka
} 


\section{Program Yang Diberikan Partai Kepada Donna Menjelang Pemilihan Legislatif Kabupaten Tanah Datar Tahun 2019}

Saat telah menjadi anggota DPRD, partai lebih memfokuskan dan mendukung program-program yang telah diinisiasinya yaitu program pemberdayaan terhadap perempuan. Lalu partai juga mengingatkan agar para kader yang menjadi anggota DPRD agar lebih maksimal dalam melakukan pengabdiannya kepada masyarakat. Serta lebih sering mengadakan kegiatan yang mempertemukan anggota partai dengan masyarakat seperti sosialisasi, temu ramah, dan dialog.

"Lebih ke mendukung ke program-program yang diinisiasinya. Seperti melakukan pemberdayaan terhadap perempuan. Disitu kami selalu solid untuk mendukung program tersebut. Selain itu kami juga selalu mengingatkan kepada kader yang menjadi anggota DPPRD agar selalu maksimal dan konsisten dalam berbakti terhadap masyarakat. Sekali juga ada kami bersama mengadakan event yang melibatkan seluruh kader partai dengan masyarakat. Disitulah saya selaku ketua DPC partai memberikan instruksi kepada kader agar fokus dalam berinteraksi dengan masyarakat. Fokus dalam menyaring aspirasi dan mendengar keluh kesah yang datang dari masyarakat. Agar kita semua tahu apa-apa saja permasalahan yang ada di masyarakat dan akan dicarikan solusi untuk mengatasinya". ${ }^{28}$

Donna sendiri dikatakan berhasil dalam menjalankan program-program partai yang diberikan kepadanya. Sehingga kepercayaan partai terhadapnya menjadi meningkat. Hal inilah yang menjadi penyebab Partai Demokrat memberikan kepercayaan lagi kepadanya untuk maju kembali menjadi calon anggota legislatif Partai Demokrat pada Pemilu 2019 dan memberikan nomor urut 1 kepadanya.

\section{f. Kredibilitas Donna}

Secara umum kredibilitas merupakan sebuah kekuatan dan kapasitas yang dimiliki oleh seseorang sehingga orang tersebut menimbulkan kepercayaan bagi orang lain. Terdapat tiga identifikasi komponen kajian yang menilai seseorang mempunyai kredibilitas yang terdapat dalam buku Rakhmad (2012:112) yaitu Keahlian, Kepercayaan dan Daya Tarik Komunikator. ${ }^{29}$ Peneliti ingin melihat tiga komponen kredibilitas ini untuk mengetahui bagaimana bentuk kredibilitas yang dimiliki oleh Donna.

\section{Keahlian}

Dalam konteks seorang anggota DPRD, topik ini berbicara tentang bagaimana kapasitas keahlian ilmu yang dimiliki oleh seorang anggota DPRD itu sendiri. Salah satu keahlian tersebut yaitu kemampuan dalam menyampaikan pendapat dan memperjuangkan aspirasi yang datang dari rakyat. Berikut temuan data yang peneliti dapatkan terkait kemampuan Donna dalam menyampaikan pendapat dan

\footnotetext{
${ }^{28}$ Wawancara dengan Nurhamdi Zahari Sekretaris DPC Partai Demokrat Kabupaten Tanah Datar 2014 dan Ketua DPC Partai Demokrat Kabupaten Tanah Datar 2019 di kediamannya Pada Tanggal 2 Maret Pukul 11.01 WIB

${ }^{29}$ Rakhmad, Jalaludin. 2012. Psikologi Komunikasi. Remaja Rosda Karya, Bandung.
} 
memperjuangkan aspirasi berdasarkan wawancara dengan Nurhamdi Zahari selaku Sekretaris DPC Partai Demokrat 2014 dan Ketua DPC Partai Demokrat 2019 Kabupaten Tanah Datar.

"Sangat bagus kemampuan komunikasi yang dimiliki oleh Donna ini. Contohnya pada saat dia di komisi 3 di DPRD pada saat ini, pada saat rapat membicarakan permasalahan jalan. Donna ini selalu bersuara dalam membicarakan permasalahan jalan yang ada di kabupaten ini. Permasalahan jalan seperti jalan rusak dan berlobang di tiga kecamatan yang ada di dapilnya selalu di bicarakan dan dia perjuangkan dengan menyertai argumen-argumen komprehensif yang membuktikan bahwa persoalan itu penting dan harus segera diatasi". ${ }^{30}$

Dikatakan Donna memiliki kemampuan komunikasi yang visioner, substansi dan efektif. Hal ini dijelaskan ketika rapat di Komisi 3 DPRD Kabupaten Tanah Datar Donna selalu mengemukakan aspirasi-aspirasi rakyat yang datang kepadanya. Menyampaikan aspirasi itu secara substansi dan komprehensif melalui pertimbangan-pertimbangan rasional dan mendukung. Kemampuan Komunikasi Donna ini dinilai sangat ampuh dalam mempengaruhi audiens sehingga memiliki peluang untuk diterima yang sangat besar sekali.

"Donna ini memang komunikasi yang dia miliki itu sangat bagus. Sering itu gagasangagasan yang disampaikan olehnya dalam sidang DPRD itu diterima. Kita tau kan bahwasanya di DPRD itu terdiri dari banyak partai yang berbeda. Nah dengan kemampuan komunikasi yang dimilki tersebut dia dapat merangkul dan membuat anggota DPRD yang dari partai lain dapat setuju dengan gagasan yang dia sampaikan. Hal ini tidak terlepas dari komunikasi tali silaturrahmi yang telah dia lakukan dengan rekan-rekan anggota DPRD lainnya yang berbeda partai dengannya". ${ }^{1}$

Terdapat penemuan menarik menurut peneliti berdasarkan hasil wawancara dengan Nurhamdi Zahari yang mengatakan bahwa Donna memiliki komunikasi yang baik sehingga membuat seluruh anggota DPRD yang berbeda partai dengannya menjadi setuju dengan pembicaraan yang disampaikannya. Peneliti mengatakan bahwa Donna memiliki kapasitas yang mumpuni dalam hal melakukan lobi politik. Menurut Mahi Hikmat (2011) Lobi Politik merupakan aktivitas komunikasi yang dilakukan oleh seorang politisi dengan tujuan mempengaruhi pimpinan dan semua hadirin yang memiliki kedudukan penting dalam organisasi pemerintah sehingga dapat mendapatkan keuntungan bagi dirinya maupun organisasi politknya. ${ }^{32}$

\section{Kepercayaan}

\footnotetext{
${ }^{30}$ Wawancara dengan Nurhamdi Zahari Sekretaris DPC Partai Demokrat Kabupaten Tanah Datar 2014 dan Ketua DPC Partai Demokrat Kabupaten Tanah Datar 2019 di kediamannya Pada Tanggal 2 Maret Pukul 11.01 WIB

${ }^{31}$ Wawancara dengan Nurhamdi Zahari Sekretaris DPC Partai Demokrat Kabupaten Tanah Datar 2014 dan Ketua DPC Partai Demokrat Kabupaten Tanah Datar 2019 di kediamannya Pada Tanggal 2 Maret Pukul 11.01 WIB

32 Mahi M. Hikmat. 2011. Komunikasi Politik. Bandung : Simbiosa Rekatama Media.
} 
Kepercayaan adalah kesan audience tentang komunikator berkaitan dengan watak atau kepribadianya. Komunikator yang dapat dipercaya adalah komunikator yang dianggap jujur, tulus, bermoral, adil, sopan atau etis. Jika khalayak menilai bahwa tindakan atau ucapan sumber didasari motif untuk mengambil keuntungan sepihak, maka ia akan menjadi kurang persuasif ketimbang sumber yang dipersuasi tidak memiliki kepentingan pribadi. Dari pernyataan tersebut, dapat disimpulkan bahwa khalayak akan percaya pada komunikator bergantung pada watak yang dimiliki oleh komunikator atau sumber itu sendiri. Jika ia dianggap jujur dan tulus dalam menyampaikan informasi, bermoral, adil, etis, serta kesopanannya dalam membuat pernyataan dan bertindak maka khalayak akan percaya. Berikut hasil wawancara peneliti dengan Nurhamdi Zahari selaku orang terdekatnya dalam lingkaran pergaulan di ranah politik:

"Donna memiliki kepribadian jujur, bermoral, adil, etis dan sopan kepada masyarakat kepada kita selaku partai dia jujur. Baik itu dalam melaporkan tentang anggran maupun permasalahan lainnya. Saat dia jadi bendahara tidak pernah satupun dana yang pernah disalahgunakannya. Ketika Donna mendapatkan dana, selalu dia sampaikan dari mana asal usul dan tujuan dari penggunaan dana tersebut. Donna sendiri termasuk anggota yang aktif dalam berpartisipasi menyumbangkan bantuan materi seperti dana itu. Namun dia tidak pernah merasa bangga dan merasa tinggi akan hal itu. Itu yang sangat kami apresiasi sekali terhadap sifat kejujuran, tulus, adil dan bermoral yang dimiliki oleh Donna tersebut". ${ }^{33}$

Dikatakan Donna memiliki kepribadian jujur, tulus, bermoral, adil dan sopan. Hal ini dibuktikan dengan temuan hasil wawancara peneliti yang mengatakan Donna saat menjadi Bendahara DPC Partai Demokrat Kabupaten Tanah Datar memiliki kinerja yang transparan dan akuntabel. Untuk mendapatkan data yang mendukung akan perihal ini peneliti juga melakukan wawancara dengan Yetri selaku sebagai masyarakat yang memilih Donna pada Pemilu 2019 lalu.

\section{Daya Tarik}

Menurut Rakhmad (2012:112) daya tarik komunikator adalah daya tarik dari penampilan fisik (physic) dan juga daya tarik psikologis yang terdiri dari kesamaan (similarity), dikenal (familiarity), atau kesukaan (liking). Kesamaan atau similarity dimaksudkan agar orang bisa tertarik pada komunikator karena adanya kesamaan demografi, seperti bahasa, agama, daerah asal, maupun ideologi. Familiarity maksudnya seorang komunikator yang dikenal baik lebih diterima oleh audience daripada mereka yang tidak dikenal. Komunikator yang sudah dikenal kepiawaiannya akan mudah diterima, sebab audience tidak akan ragu terhadap kemampuan dan kejujurannya. Kesukaan atau liking artinya komunikator yang disukai karena penampilan fisiknya, adanya kesamaan, atau dikenal baik akan lebih memiliki daya tarik. Temuan peneliti yang

\footnotetext{
${ }^{33}$ Wawancara dengan Nurhamdi Zahari Sekretaris DPC Partai Demokrat Kabupaten Tanah Datar 2014 dan Ketua DPC Partai Demokrat Kabupaten Tanah Datar 2019 di kediamannya Pada Tanggal 2 Maret Pukul 11.01 WIB
} 
menjelaskan tentang komponen dari daya tarik karena penampilan fisik terhadap memilih Donna yaitu:

"Sebenarnya alasan saya memilih Ibuk Donna lebih ke pribadinya sih. Bagiamana dia dengan masyarakat dan perannya terhadap masyarakat yang membuat saya memilih ibuk itu. Kalu soal penampilan fisik dari Ibuk Donna itu gak begitu berpengaruh dalam membuat orang untuk memilihnya. Tetapi ada juga masyarakat yang memilih caleg ini dengan berdasarkan pertimbangan itu. Saya menilai Buk Donna ini memang orangnya itu cantik sehingga mungkin karena penampilannya itu masyarakat dapat tergerak untuk memilihnya. Namun itu bukan penyebab utama yang menjadi seseorang untuk memilihnya". ${ }^{34}$

Berdasarkan hasil wawancara peneliti dengan Yetri dikatakan bahwa penampilan fisik tidak menjadi dasarnya dalam memilih Donna. Yetri memilih Donna karena sering memberikan konstribusi kepada masyarakat. Lain hal dengan Yetri dimana Asni sebagai masyarakat yang memilih Donna lainnya mengatakan bahwa penampilan Donna yang cantik memiliki pengaruh baginya untuk memilih Donna pada Pemilu 2014 dan 2019.

Kemudian untuk memperkuat pengetahuan tentang faktor daya tarik komunikator dari segi penampilan ini dapat membuat perilaku memilih masyarakat menjadi berpengaruh, peneliti juga melakukan wawancara dengan Ketua Pusat Kajian Wanita FISIP UNAND Dr Jendrius yang mengatakan:

"Memiliki Pengaruh, sesuai juga dengan konsepsi teori psikologi massa bahwa penampilan dari seseorang itu sangat berpengaruh sekali sebagai acuan dalam memilih. Contohnya Pak SBY yang memiliki badan kekar,sigap, tegas sehingga banyak orang yang terkagum akan penampilannya itu". ${ }^{35}$

\section{KESIMPULAN}

Hasil dari penelitian ini menunjukkan bahwa Donna memiliki partisipasi dan konstribusi yang baik terhadap organisasi partai politiknya. Dimana Donna selalu terlibat aktif dalam kegiatan pengambilan keputusan seperti rajin mengikuti kegiatan rapat partai dan selalu aktif berkonstribusi dalam merumuskan kebijakan. Donna juga sering memberikan gagasan yang bernilai kepada partainya diantaranya yang sangat potensial menurut hemat peneliti yaitu; tentang tata cara melakukan rekruitmen politk , implementasi program pemberdayaan terhadap perempuan, pentingnya melakukan evaluasi kinerja, mengingatkan seluruh lapisan ketua agar selalu melakukan konsolidasi kader partai, dan selalu mencetuskan program kepartaian yang selalu berorientasi akan memperjuangkan kepentingan masyarakat.

\footnotetext{
${ }^{34}$ Wawancara dengan Yetri Selaku Masyarakat yang memilih Donna Pada Pemilu Legislatif 2014 dan 2019 Kabupaten Tanah Datar di kediamannya Pada Tanggal 4 Maret 2021 Pukul 10.50 WIB

${ }^{35}$ Wawancara dengan Dr. Jendrius Ketua Pusat Kajian Wanita FISIP UNAND/Dosen Sosiologi Universitas Andalas di Gedung Jurusan Sosiologi Unand Pada Tanggal 17 Maret 2021 Pukul 11.17 WIB
} 
Dalam hal sumbangsih tenaga kepada partai Donna selalu rutin hadir untuk mengikuti setiap agenda atau program yang telah diagendakan oleh partai dan aktif berkonstribusi menyukseskan kegiatan tersebut. Dari aspek materi Donna rutin dalam menyumbangkan materi berupa donasi untuk partai. Kemampuan bekerja sama Donna sangat baik karena Donna selalu membangun komunikasi dengan sesama rekan partainya. Sehingga tali silaturrahmi dapat terjalin dan juga Donna selalu mengajak rekan-rekan kader Partai Demokrat agar selalu meningkatkan rasa solidaritas.

Menelusuri peran Donna kepada masyarakat sebelum menjadi anggota DPRD Donna sering melakukan komunikasi dan menjalin silaturrahmi dengan masyarakat. Donna juga sering menjadi donatur dalam kegiatan pembangunan, membantu masyarakat yang kurang mampu, memberikan beasiswa pendidikan. Saat telah menjadi anggota DPRD Dona_Semakin sering turun ke masyarakat dan maksimal dalam menyerap aspirasi masyarakat Serta militan dalam mengoptimalkan mengimplementasikan program pemberdayaan perempuan yang digagasnya.

Berkaca pada Teori Lovenduski dan Norris (1993:12) yang membahas tentang bagaimana program yang datang dari sebuah partai. Temuan peneliti menunjukkan program yang diberikan Partai Demokrat kepada Donna menjelang Pemilihan Legislatif Kabupaten Tanah Datar Tahun 2019 Mendukung program yang diinisiasi oleh Donna seperti program pemberdayaan perempuan. Program menjelang Pemilihan Legislatif Tahun 2019 yaitu Menginstruksikan kepada kader yang menjadi anggota DPRD agar lebih intens dalam mengabdi kepada masyarakat dan sering mengadakan sosialisai, temu ramah, dan dialog dengan masyarakat. Dari semua program itu Donna menjalankannya dengan baik.

Kredibilitas sebagaimana yang terdapat dalam buku Rakhmad (2012:112) tentang indikator yang menunjukkan seorang yang dianggap memiliki kredibilitas yaitu Keahlian, Kepercayaan dan Daya Tarik Komunikator. Keahlian yang dimiliki oleh Donna yaitu memiliki komunikasi yang sangat baik.Donna dipercayai oleh partai dan masyarakat yang memilihnya karena Donna memiliki kepribadian jujur, tulus, bermoral, adil dan sopan. Penampilan fisik Donna tidak terlalu menjadi alasan masyarakat tertarik untuk memilihnya.Sedangkan adanya Kesamaan demografi, seperti bahasa, agama, daerah asal dan ideologi (similiarity)masyarakat dengan Donna menjadi faktor yang kuat dalam membuat masyarakat menjadi memilih Donna.

Berdasarkan hasil temuan peneliti Donna merupakan orang yang sangat dikenal dalam lingkungan masyarakat. Atas dasar penemuan ini peneliti menyimpulkan bahwa Donna merupakan orang yang kredibel di lingkungan sosialnya. Dengan aktifnya Donna berpartisipasi memberikan konstribusi kepada partainya, selalu sukses dalam melaksanakan program yang diberikan oleh partai dan juga dapat membuat dirinya menjadi seseorang yang kredibel. 


\section{DAFTAR PUSTAKA}

Adman Nursal, Political Marketing, Jakarta: Gramedia.2004. hal 23

Afifudin \& Beni Ahman Saebani, 2009, Metodologi Penelitian Kualitatif, Bandung:CV Pustaka SetiaAkbar Islamsyah, Fikrian. 2018. Analisis Kemenangan MarzuqiAndi Pada Pilkada Jepara 2017. Journal of Politics and Government Studies Vol 7, No 04 (2018) : Periode Wisuda Oktober 2018.

Aruni, Fidia. 2016. GENDER DAN POLITIK, Keterwakilan Wanita Dalam Politik. Lhokseumawe: Aceh : UNIMAL PRESS

Astrid Anugrah, Keterwakilan Perempuan Dalam Politik, Pancuran Alam, Cetakan Kedua, Mei 2009, Jakarta, Hlm 28-29.

Azwar S. 2011. Sikap Manusia: Teori dan Pengukurannya. Gramedia Pustaka, Jakarta.

Baleri, Dio, 2017, Strategi Pemenangan Herman HN-Yusuf Kohar dalam Pemilihan Walikota-Wakil Walikota Bandar Lampung Periode 2016-2021

Basuki, H. 2006. Penelitian Kualitatif Untuk Ilmu Kemanuasiaan dan Budaya. Depok: Universitas Gunadarma.

BPS Kabupaten Tanah Datar, 2019. Tanah Datar dalam Angka in Figure 2019, BPS, Tanah Datar, 2019

Budiarjo, Miriam. (2008). "Dasar-Dasar Ilmu Politik, Edisi Revisi” Jakarta. PT. Gramedia Pustaka Utama.

Dan Nimmo, 2005, Komunikasi Politik, Bandung: Rosdakarya

Dawy, H.M. 1992. Partisipasi Masyarakat dalam Pengembangan Kepariwisataan Yang Berwawasan Lingkungan. Ujung Pandang: Program Pascasarjana UNHAS.

Gibson. 2006. Perilaku Organisasi. Buku 1 Edisi Kedua Belas. Alih Bahasa Diana Angelina. Jakarta : Salaemba Empat

Heru Permana Putra, "Perbandingan Strategi Anggota Legislatif Perempuan Di DPRD Kota Padang Pada Pemilu Legislatif Tahun 2009”. Skripsi Pada Jurusan Ilmu Politik FISIP UNAND, Padang,2011.

Ida Rosdalina, 1999, Konvensi Penghapusan Segala Bentuk Diskriminasi Terhadap Perempuan, Jakarta: LSPP, hal 4.

Lexy J. Moleong, 2009, Metode Penelitian Kualitatif, Bandung:PT Remaja Rosdakarya

Lovenduski, Joni \& Norris, Pippa. 1993. Gender and Party Politics. London: Sage Publications

M. Alfan Alfian, 2012, Kekuatan Pemimpin, Jakarta: Kubah Ilmu

Mahi M. Hikmat. 2011. Komunikasi Politik. Bandung : Simbiosa Rekatama Media

Makalah Kebijakan, “Partisipasi Perempuan Dalam Politik dan Pemerintahan”, UNDP Indonesia, 2010

Mauruce Duferger. 2012. Sosiologi Politik. Jakarta : Gramedia Pustaka

Midgley, J. 1986. Introduction: Social Development in Midgley J. Et All Community participation social development and the state. London: Meuthen.Co. 
Muluk, Hamdi, 2010, Mozaik Psikologi Politik Indonesia, Jakarta:Raja Wali Press

Oakley dan Fakih, sebagaimana dikutip Dewi Rostyaningsih. 2013. Konsep Gender. Jakarta : PT Gravindo

Pabeta. 1992. Meningkatkan Partisipasi Terhadap Organisasi. Jakarta : PT Gramedia Pustaka Jaya

Prijono, O.S, Pranarka, A. M. W. 1996. Pemberdayaan: Konsep, Kebijakan dan Implementasi. CSIS. Jakarta.

Qodir, Zuly \& Putri, Masdiyan. Faktor Kemenangan Koalisi Suharsono-Halim dalam Pemenangan Pemilu Kepala Daerah Kabupaten Bantul Tahun 2015. Prosiding Interdisplinary Postgraduate Studen Conference

Rakhmad, Jalaludin. 2012. Psikologi Komunikasi. Remaja Rosda Karya, Bandung

Ross, Marc Howard Ross. 1993. The Management Of Conflict : Interpretations and interest in comparative perspective. Yale University Press.

Roth, Dieter. 2008. Studi Pemilu Empiris, Sumber, Teori dan Metode. Jakarta : FriedrichNaumann Stiftung Fur Die Freihet.

Steers, R.M dan Potter, L.W. 1983. Motivation and Work Behavior, New York : Academic Press

Stella Maria Ignasia Pantouw, 2012, Modalitas Dalam Kontestasi Politik (Studi Tentang Modalitas Dalam Kemenangan Pasangan Hanny Sondakh dan Maximiliaan Lomban Pada Pemilukada di Kota Bitung Sulawesi Utara Tahun 2010), Thesis, Universitas Diponegoro

Sukmana, Oman. 2016. Konsep dan Teori Gerakan Sosial. Malang : Intrans Publishing 